\title{
Potential for Integrated Control of Sclerotinia sclerotiorum in Glasshouse Lettuce Using Coniothyrium minitans and Reduced Fungicide Application
}

\author{
Simon P. Budge and John M. Whipps
}

Plant Pathology and Microbiology Department, Horticulture Research International, Wellesbourne, Warwick, CV35 9EF, U.K. Accepted for publication 20 November 2000.

\begin{abstract}
Budge, S. P., and Whipps, J. M. 2001. Potential for integrated control of Sclerotinia sclerotiorum in glasshouse lettuce using Coniothyrium minitans and reduced fungicide application. Phytopathology 91:221-227.

All pesticides used in United Kingdom glasshouse lettuce production (six fungicides, four insecticides, and one herbicide) were evaluated for their effects on Coniothyrium minitans mycelial growth and spore germination in vitro agar plate tests. Only the fungicides had a significant effect with all three strains of $C$. minitans tested, being highly sensitive to iprodione (50\% effective concentration $\left[\mathrm{EC}_{50}\right] 7$ to $18 \mu \mathrm{g}$ a.i. $\mathrm{ml}^{-1}$ ), moderately sensitive to thiram $\left(\mathrm{EC}_{50} 52\right.$ to $106 \mu \mathrm{g}$ a.i. $\left.\mathrm{ml}^{-1}\right)$, but less sensitive to the remaining fungicides $\left(\mathrm{EC}_{50}\right.$ over $200 \mu \mathrm{g}$ a.i. $\left.\mathrm{ml}^{-1}\right)$. Subsequently, all pesticides were assessed for their effect on the ability of $C$. minitans applied as a solid substrate inoculum to infect sclerotia of Sclerotinia sclerotiorum in soil tray tests. Despite weekly applications of pesticides at twice their recommended concentrations, C. minitans survived in the soil and infected sclerotia equally in all pesticide-treated and

these results, solid substrate inoculum of a standard and an iprodionetolerant strain of $C$. minitans were applied individually to $S$. sclerotiorum-infested soil in a glasshouse before planting lettuce crops. The effect of a single spray application of iprodione on disease control in the C. minitans treatments was assessed. Disease caused by S. sclerotiorum was significantly reduced by $C$. minitans and was enhanced by a single application of iprodione, regardless of whether the biocontrol agent was iprodione-tolerant. In a second experiment, disease control achieved by a combination of $C$. minitans and a single application of iprodione was shown to be equivalent to that of prophylactic sprays with iprodione every 2 weeks. The fungicide did not affect the ability of $C$. minitans to spread into plots where only the fungicide was applied and to infect sclerotia. These results indicate that integrated control of S. sclerotiorum with soil applications of $C$. minitans and reduced foliar iprodione applications was feasible, did not require a fungicide tolerant isolate, and that suppression of Sclerotinia disease by $C$. minitans under existing chemical control regimes has credence.
\end{abstract} untreated control soil trays. This demonstrated the importance of assessing pesticide compatibility in environmentally relevant tests. Based on

The sclerotial mycoparasite, Coniothyrium minitans Campbell, is an effective antagonist and biocontrol agent of the plant pathogen Sclerotinia sclerotiorum (Lib.) de Bary (18,30,32,34,52). As with other potential biocontrol agents, however, the ability of $C$. minitans to control Sclerotinia disease can diminish when disease pressure increases. In previous glasshouse lettuce trials, C. minitans consistently achieved over $60 \%$ control of S. sclerotiorum when disease incidence approached $50 \%$, but this level of control was quickly lost as the amount of disease increased $(5,6,26,50)$. To overcome such problems, one approach is to search for more efficient isolates of $C$. minitans. From a worldwide collection of C. minitans isolates, however, little difference in ability to prevent infection of plant tissue and to reduce sclerotial production and infection has been found (17). Improving activity by manipulating inoculum production and formulation is another strategy (15), but a range of $C$. minitans isolates produced in a variety of solid substrates or in liquid culture, and incorporated into soil, showed little difference in ability to infect sclerotia of $S$. sclerotiorum and provide disease control in glasshouse lettuce $(32,34)$.

Another approach to enhance the activity of $C$. minitans is to develop integrated control strategies $(37,48)$. Considerable research has been done on integrating biocontrol agents with fungicides. Most studies have considered integration of fungal

Corresponding author: J. Whipps; E-mail address: john.whipps@hri.ac.uk

Publication no. P-2000-1218-02R

(C) 2001 The American Phytopathological Society
Additional keywords: mycoparasite, protected lettuce. biocontrol agents with fungicides in foliar $(6,12,13,20,40,41$, $42,43,56,59,60)$, soil and seed $(1,8,9,35,36,38)$, or postharvest $(7,10,39)$ environments. Integration of bacterial biocontrol agents with fungicides has been examined but to a lesser extent, in foliar (24), soil and seed $(4,27,29,47,58)$, and postharvest (39) environments. In many of these studies increased disease control was achieved from combinations of the biocontrol agent with the fungicide applied at the full rate. Nevertheless, the use of fungicides at normal rates and application frequencies in such integrated systems seems to negate the principle of using biological agents to reduce pesticide use. There has been some work, however, involving the use of lower amounts of fungicide in integrated systems, either through a combination of a lower dose applied simultaneously with a biocontrol agent $(7,8,10,20,28,43)$, or by using alternating treatments of chemicals and biocontrol agents $(13,20,40,41)$. This approach reduces the environmental risks pressure. To achieve a fully integrated control program, however, it is important to ascertain if selected natural biocontrol agents or those trained or mutagenized to be more resistant to specific fungicides, are more tolerant of other fungicides, insecticides, selective herbicides, and antibiotics used within the same crop. This is gradually becoming more appreciated $(1,11,12,14,21$, 25,41,57).

Consequently, the aim of this study was to evaluate the sensitivity of $C$. minitans to all pesticides used in the production of glasshouse lettuce in the United Kingdom and to determine whether effective integrated control of $S$. sclerotiorum could be achieved with this agent with reduced application of the fungicide iprodione. 


\section{MATERIALS AND METHODS}

Fungi and inoculum production. An isolate of S. sclerotiorum was originally obtained from diseased glasshouse lettuce and was maintained on potato dextrose agar (PDA) (Unipath Ltd., Basingstoke, U.K.). Sclerotia used for the soil tray experiments were produced by autoclaving $25 \mathrm{~g}$ of wheat grain (cv. Armada) and $50 \mathrm{ml}$ of water in $250-\mathrm{ml}$ conical flasks for $15 \mathrm{~min}$ at $121^{\circ} \mathrm{C}$, then inoculating the grain with three 10 -mm diameter agar plugs cut from $S$. sclerotiorum plate cultures. After 3 weeks of incubation at $20^{\circ} \mathrm{C}$, sclerotia were removed and graded to use those between 2- to 4-mm diameter.

One standard isolate of $C$. minitans (Conio; IMI 134523) was used in all experiments and was originally isolated from a sclerotium of S. sclerotiorum (45). Two other isolates of $C$. minitans were employed in in vitro tests: IVT-1, isolated from a sclerotium of S. sclerotiorum (17), and $\mathrm{CH} 1$, isolated from soil (51). An iprodione-tolerant strain of $C$. minitans (derived from Conio) used in the first glasshouse trial was obtained during the in vitro plate tests; restricted colonies of $C$. minitans growing on PDA containing high concentrations of iprodione (500 mg liter ${ }^{-1}$ ) frequently sectored to give mycelium growing at normal rates. Single spore isolates from the fast-growing sectors were made and the most stable isolate was maintained alternatively on PDA and PDA incorporating $500 \mathrm{mg} \mathrm{liter}^{-1}$ of iprodione. Stability of fungicide resistance was tested by subculturing eight times on PDA and transferring onto iprodione-containing media.

Maizemeal-perlite inoculum of $C$. minitans used in the tray tests and glasshouse trials was prepared by adding 1.7 liters of perlite (horticultural grade; Silvaperl, Gainsborough, U.K.), $300 \mathrm{ml}$ of ground maize (2- to 5-mm diameter; Bartholomews, Chichester, U.K.) and $400 \mathrm{ml}$ of tap water into mushroom spawn bags $(22.5 \times 56 \mathrm{~cm}$; Van Leer, Poole, UK) and autoclaving for $15 \mathrm{~min}$ at $121^{\circ} \mathrm{C}$. Bags were inoculated with $100 \mathrm{ml}$ of a spore suspension of $C$. minitans (approximately $10^{6}$ conidia per ml) made by flooding 14-day-old PDA plate cultures with sterile water and gently scraping the colony surface with a spatula. Inoculated bags were incubated at $18^{\circ} \mathrm{C}$ for 21 days. Previous studies $(5,6)$ have demonstrated that this inoculum consistently contains between $7 \times$ $10^{7}$ to $4 \times 10^{8} \mathrm{CFU} / \mathrm{cm}^{3}$ fresh material.

Pesticides. All pesticides were commercial formulations approved for use in glasshouse lettuce in the United Kingdom (53). Fungicides used in the in vitro plate tests were: iprodione (Rovral WP, $50 \%$ a.i.; maximum recommended application rate (MRAR) $500 \mathrm{~g} \mathrm{ha}^{-1}$ ); mancozeb (Karamate Dry Flo, 75\% a.i.; MRAR $3.9 \mathrm{~kg} \mathrm{ha}^{-1}$ ); metalaxyl plus thiram (Favour $600 \mathrm{SC}$, 10\% plus $50 \%$ a.i.; MRAR 3.0 liter $\mathrm{ha}^{-1}$ ); thiram (Unicrop Thiosan DG, $80 \%$ a.i.; MRAR $4 \mathrm{~g} \mathrm{liter}^{-1}$ sprayed to run-off); tolclofos-methyl (Basilex 50\% a.i.; MRAR $20 \mathrm{~kg} \mathrm{ha}^{-1}$ ); and zineb (Unicrop Zineb, $70 \%$ a.i.; MRAR $2 \mathrm{~g} \mathrm{liter}^{-1}$ sprayed to run-off). Insecticides used in in vitro plate tests were: cypermethrin (Ambush C, $10 \%$ a.i.; MRAR $250 \mathrm{ml} \mathrm{ha}^{-1}$ ); dimethoate (BASF Dimethoate 40, $40 \%$ a.i.; MRAR $850 \mathrm{ml} \mathrm{ha}^{-1}$ ); malathion (Malathion 60, 60\% a.i.; MRAR 2.1 liters $\mathrm{ha}^{-1}$ ); and pirimicarb (Standon Pirimicarb $\mathrm{H}, 50 \%$ a.i.; MRAR $0.5 \mathrm{~g} \mathrm{liter}^{-1}$ sprayed to run-off). The herbicide chlorpropham with cetrimide (Croptex Pewter, $8 \%$ plus $8 \%$ a.i.; MRAR 11 liters ha ${ }^{-1}$ ) was used for in vitro plate tests. For soil tray tests, all the above chemicals were used as well as the fumigant fungicide, dicloran (Fumite Dicloran Smoke, Hortichem, $40 \%$ a.i.; MRAR $90 \mathrm{mg}$ a.i. per $\mathrm{m}^{3}$ ) and the fumigant insecticide, pirimiphos-methyl (Fumite Pirimiphos Methyl Smoke, Hortichem, $22.5 \%$ a.i.; $50 \mathrm{mg}$ a.i. per $\mathrm{m}^{3}$ ).

In vitro pesticide tests. The effect of each pesticide on radial growth rate and conidial germination of the three isolates of $C$. minitans was tested on PDA amended with a range of seven concentrations determined from preliminary experiments up to a maximum of twice the manufacturers' application dosage. Pesticides were added to the agar at $50^{\circ} \mathrm{C}$ before adding $15 \mathrm{ml}$ of the medium to each petri dish. Radial growth was determined by placing 5-mm disks cut from the growing edge of 7-day-old PDA cultures upside down in the center of the test plate. Growth was measured on four set radii every $48 \mathrm{~h}$ for 12 days at $20^{\circ} \mathrm{C}$. Conidial germination was tested by spraying approximately $0.05 \mathrm{ml}$ of spore suspension $\left(2 \times 10^{6}\right.$ spores per $\left.\mathrm{ml}\right)$ onto the plate surface with an atomizer. After the plates were incubated for $32 \mathrm{~h}$, germination was assessed by flooding the plates with Cotton Blue in lactophenol and counting the number of germinated conidia out of 100 in three set areas of the plates. For all treatments there were 20 replicate plates, and all experiments were conducted three times.

Soil-tray experiments. The aim of these experiments was to evaluate the toxicity of pesticides to $C$. minitans and the effects of pesticides on colonization of sclerotia by the biocontrol agent in soil. Plastic trays, $53 \times 38 \times 7.5 \mathrm{~cm}$, with small holes in the bottom for drainage, were first filled with $2 \mathrm{~cm}$ of gravel, then a $2-\mathrm{cm}$ layer of unsieved soil (brickearth; silt loam, Hamble Series), and finally a $3-\mathrm{cm}$ layer of the same sieved $(5.6 \mathrm{~mm})$ soil. The soil was moistened to $75 \%$ field capacity. Maizemeal-perlite inoculum of $C$. minitans $\left(120 \mathrm{ml}\right.$ per tray $=0.6$ liters $\mathrm{m}^{-2}$ ) was added to appropriate trays and lightly worked into the layer of sieved soil. This rate provided reproducible disease control and infection of sclerotia in previous experiments $(5,6)$. Fifty sclerotia of $S$. sclerotiorum were lightly pressed into the soil surface of each tray so they were evenly spaced and remained just visible. For each pesticide, there were four treatments: first, sclerotia only; second, sclerotia plus pesticide; third, sclerotia plus $C$. minitans; and fourth, sclerotia plus $C$. minitans plus pesticide. Pesticides were applied at double the manufacturer's recommended rate immediately after setting up the trays and three times thereafter at weekly intervals. Applications were made by spraying the two treatment (second and fourth) trays placed within a $1-\mathrm{m}^{2}$ area with the appropriate volume of pesticide. Volumes were calculated from those applied to glasshouse lettuce until run-off, for a given area. For the two fumigant pesticides, the trays were placed within a glasshouse that was half the volume of that appropriate for the fumigant generating unit to double the application rate. All trays were covered with a second empty tray placed upside down on top of the filled tray and incubated at $18^{\circ} \mathrm{C}$ for 4 weeks. Soil moisture was maintained by spraying water onto the soil surface with a hand sprayer.

Soil samples $(5 \mathrm{ml})$ were taken from three points in each tray immediately after addition of inoculum and each week thereafter. Because C. minitans does not grow through soil $(54,55), C$. minitans survival was assessed by soil dilution plating using PDA amended with Triton X-100 (2 $\left.\mathrm{ml} \mathrm{liter}^{-1}\right)$ and chlortetracycline (20 mg liter ${ }^{-1}$ ). After 4 weeks, all sclerotia were removed, surface sterilized, bisected, and placed onto 15-mm PDA disks containing chlortetracycline using a modification to the original technique (49). In the modified system, after surface sterilization, sclerotia were individually rinsed in $2 \mathrm{ml}$ of sterile water contained within a compartmentalized square petri dish (Bibby Sterilin, Stone, U.K.). After shaking the plate gently on a small platform shaker, sclerotia were individually transferred to a second segmented petri dish and shaken again. This modification eliminated the potential problem of spores of $C$. minitans being disseminated from a single heavily infected sclerotium to contaminate those uninfected by the antagonist that may occur during batch washing of sclerotia. Numbers of viable sclerotia and those infected by $C$. minitans were recorded after 14 days. Three replicate runs of the complete set of pesticide treatments were carried out with each treatment comprising three trays of 50 sclerotia.

First glasshouse trial: Use of iprodione-tolerant mutant of C. minitans. A single glasshouse (Cambridge Alumabrite) chamber $(13 \times 9 \mathrm{~m})$ used for previous trials of $S$. sclerotiorum on lettuce (5), was sheet steamed and planted with a crop of lettuce (cv. Hudson) following standard horticultural practices. Steaming is a standard procedure for glasshouse crops in the United Kingdom and is becoming more common following the constraints on 
the use of soil sterilant methyl bromide. Glasshouse temperatures were maintained at $10^{\circ} \mathrm{C}$ minimum day temperature, with vents opening at $18^{\circ} \mathrm{C}$ and with a $5^{\circ} \mathrm{C}$ minimum night temperature. Sclerotia were established in the soil by artificially inoculating the lettuce with $0.5-\mathrm{cm}$ PDA mycelial disks of S. sclerotiorum onto wounds made on leaf petioles. Following harvest of healthy plants, diseased material was allowed to dry on the soil surface. Sclerotia that formed were evenly spread throughout the glasshouse chamber and the soil rotovated to a depth of $15 \mathrm{~cm}$. Twenty plots $(1.8 \times 1.6 \mathrm{~m})$ separated by $0.5-\mathrm{m}$ paths were marked out, to give four plots across and five plots down the north-south orientated chamber. The number of sclerotia present on the soil surface within the plots were assessed by counting those in five randomly selected quadrats $\left(500 \mathrm{~cm}^{2}\right)$ in each plot. Mean numbers of sclerotia ranged between 0.4 and 2.6 per quadrat.

There were five treatments: control, no treatment; standard $C$. minitans only; standard $C$. minitans plus single Rovral spray; iprodione-tolerant $C$. minitans only; and iprodione-tolerant $C$. minitans plus single Rovral spray. The treatments were randomized within the 20 plots in an incomplete Latin square arrangement, with four replicate plots per treatment each containing 72 plants. Three crops of lettuce were grown sequentially: the first was planted in mid-July and harvested in late August; the second was planted in mid-September and harvested in mid-November; and the third was planted in early December and harvested in early March. Immediately before planting each crop, 1.7 liters (0.6 liters $\mathrm{m}^{-2}$ ) of $C$. minitans maizemeal-perlite inoculum was evenly applied to each appropriate plot and raked into the soil surface to a depth of approximately $3 \mathrm{~cm}$. The single application of Rovral WP $(0.5 \mathrm{~kg} / \mathrm{ha})$ was applied during each lettuce crop to the appropriate plots until run-off as disease symptoms first began to proliferate (26).

Each crop was harvested and the number of S. sclerotioruminfected plants assessed, leaving diseased material on the plot surface. The number of sclerotia present on the soil surface in each plot were then counted using the quadrat system described earlier. From three of the quadrats in each plot, 20 sclerotia were sampled, and if there were insufficient numbers within a quadrat, the nearest adjacent sclerotia were selected for evaluation. All sampled sclerotia were evaluated for viability and infection by $C$. minitans as described above. In preliminary tests, attempts were made to distinguish the iprodione-tolerant strain from the standard strain of $C$. minitans in infected sclerotia. Due to the frequent appearance of iprodione tolerance in the standard $C$. minitans strain, however, sclerotia that were heavily infected with the standard strain of $C$. minitans repeatedly gave rise to colonies able to grow out on the fungicide-amended agar. Consequently, differentiation between infection by the standard isolate and iprodionetolerant strain in sclerotia was not possible.

Throughout each crop, soil samples were taken from the top $5 \mathrm{~cm}$ in each plot immediately after planting, at 3-week intervals thereafter, and again at harvest. C. minitans populations were assessed as described earlier. Again, initial efforts to differentiate between standard and iprodione-tolerant strains of $C$. minitans proved unsuccessful and, therefore, results are given for total numbers only.

After all sampling, plots were individually dug and raked to a depth of approximately $15 \mathrm{~cm}$ before application of $C$. minitans inoculum and planting of the next crop.

Second glasshouse trial: Use of standard $C$. minitans and single iprodione spray versus standard iprodione spraying regime. The same glasshouse chamber was used for the second glasshouse trial after thorough steam-sterilization of the soil. Disease inoculum was re-established as described for the first glasshouse trial and the same experimental design was implemented. Sclerotial numbers were assessed as before and ranged between 0.2 and 3.2 per quadrat.

There were five treatments: control (no treatment), single Rovral spray, Rovral spray applications every 2 weeks, standard
C. minitans only, and standard C. minitans plus single Rovral spray. The treatments were rerandomized to differentiate this second glasshouse trial from the first trial. Three crops were grown sequentially with the planting and harvest times for each crop similar to the first glasshouse trial. Plant disease, sclerotial numbers, sclerotial viability and infection, and survival of $C$. minitans in the soil were all assessed and recorded as for the first trial.

Statistical analysis. For the in vitro pesticide tests, data from all three repeat runs were analyzed separately by analysis of variance (ANOVA) and as the variances were found to be similar, the three complete data sets were combined. Inhibition of radial growth and spore germination were calculated as a percentage of the corresponding control, and pesticide concentrations required to inhibit growth or spore germination by $50 \%\left(\mathrm{EC}_{50}\right)$ were estimated from regression analysis of percentages against the common logarithm of percentage concentration.

A formal analysis on the sclerotial data from the soil tray experiments was considered unnecessary as every replicate run provided consistently large differences in viability, i.e., where $C$. minitans was applied, sclerotial viability was always below $20 \%$, whereas in control treatments without $C$. minitans the sclerotial viability was always over $88 \%$.

CFU data were subjected to ANOVA after $\log _{10}$ transformation and treatment means compared using the least significant difference (LSD) at a level of $P<0.05$, where appropriate, based on the $F$ test in ANOVA. Complete data sets from both glasshouse experiments were subjected to ANOVA after angular transformation of percentage data and square-root transformation of sclerotial number data. The models incorporated row and column effects to account for the incomplete Latin Square structure and the sequential harvests were treated as a split-plot. Significant differences between treatments were assessed using least significant difference (LSD) $(P<0.05)$, where appropriate, based on the $F$ test in ANOVA. These fully replicated glasshouse experiments were not repeated as numerous previous experiments using the same experimental design and basic procedures $(5,6,32,34,50)$ demonstrated the reproducibility of the type of results obtained in this system.

\section{RESULTS}

In vitro pesticide tests. Of the 11 pesticides tested, all fungicides and 2 insecticides had some effect on radial growth and spore germination of the three isolates of $C$. minitans (Table 1). Insecticides malathion and pirimicarb only reduced growth rate and spore germination at concentrations above their maximum recommended application rates. The most toxic fungicides were iprodione $\left(\mathrm{EC}_{50} 7\right.$ to $18 \mu \mathrm{g}$ a.i. $\left.\mathrm{ml}^{-1}\right)$ followed by thiram $\left(\mathrm{EC}_{50}\right.$ 52 to $106 \mu \mathrm{g}$ a.i. $\mathrm{ml}^{-1}$ ). Sensitivity of $C$. minitans to the remaining fungicides was relatively less, when effects were only found at concentrations over $200 \mu \mathrm{g}$ a.i. $\mathrm{ml}^{-1}$. There were no consistent differences in sensitivity between the isolates of $C$. minitans, or between their responses of growth rate and spore germination. Sectoring of $C$. minitans was frequently observed during growth on iprodione-amended PDA plates.

Soil-tray experiments. When all the pesticides tested were applied weekly at twice their recommended dose rate, none affected either the survival of the three strains of $C$. minitans, or their capacity to infect sclerotia relative to the untreated controls (data not shown). Briefly, the number of CFU remained constant over the 4-week period of the tests between 0.2 to $5.6 \times 10^{6} \mathrm{CFU} / \mathrm{cm}^{3}$ of soil. The level of infection of sclerotia by all isolates of C. minitans was always greater than $80 \%$ and was normally over $95 \%$. Sclerotial viability in $C$. minitans treatments was reduced to less than $20 \%$ in comparison with control treatments lacking $C$. minitans where sclerotial viability was always over $88 \%$.

First glasshouse trial: Use of iprodione-tolerant mutant of C. minitans. Very little disease was present at harvest of the first 
crop, when only $3 \%$ of control plants became infected with $S$. sclerotiorum (Table 2). In the second crop, disease incidence increased with $63 \%$ of control lettuce infected at harvest. All treatments significantly controlled $S$. sclerotiorum in the second crop but no differences in effect between individual treatments were found from the LSD test. However, in a separate analysis when the treatment pairs were considered together, the combined treatments (fourth and fifth) of both $C$. minitans and single Rovral sprays gave significantly better control than $C$. minitans when no Rovral (treatments two and three) was applied. In the third crop, although the level of control was reduced, all treatments except the iprodione-tolerant $C$. minitans (third treatment) again significantly controlled S. sclerotiorum disease, when $55 \%$ of control lettuce became infected. In this crop, the combined $C$. minitans and Rovral treatments gave significantly more disease control than the $C$. minitans-only treatments. There were no differences between the standard and iprodione-tolerant strains of $C$. minitans in their ability to control disease in all crops.

The numbers of sclerotia counted on the soil surface after harvest of the first crop were small due to the low level of disease present (Table 2). All treatments significantly reduced the number of sclerotia in the second and third crops. There was a significant reduction in sclerotial viability in the second and third crops by all treatments with the exception of the iprodione-tolerant $C$. minitans in the third crop. Over $90 \%$ of sclerotia recovered were infected by $C$. minitans in all treated plots. Infection of sclerotia by $C$. minitans in control plots was significantly less than in other plots. Nevertheless, 58\% became infected in the second crop and $73 \%$ were infected in the third crop.

Populations of $C$. minitans in the soil were the same in all $C$. minitans treatments. Following solid substrate incorporation before the first crop was planted, $C$. minitans populations were between 0.8 to $3.4 \times 10^{7} \mathrm{CFU} / \mathrm{cm}^{3}$ of soil (data not shown). By the end of the first crop numbers ranged between 2.7 to $8.2 \times$ $10^{6} \mathrm{CFU} / \mathrm{cm}^{3}$ of soil. In the second crop, CFU were initially between 0.9 to $4.6 \times 10^{7}$, then declined to between 0.6 to $1.2 \times$ $10^{7} \mathrm{CFU} / \mathrm{cm}^{3}$ of soil at harvest. During the third crop, numbers of C. minitans were initially at 1.1 to $3.8 \times 10^{7}$, then declined to between 4.8 to $9.2 \times 10^{6} \mathrm{CFU} / \mathrm{cm}^{3}$ of soil at harvest.

Second glasshouse trial: Use of standard $C$. minitans and single iprodione spray versus standard iprodione spraying regime. Disease severity in the first crop was low with $12 \%$ of control plants infected (Table 3). All treatments significantly reduced disease incidence in the first crop. In the second crop, 32\% of control plants became infected by S. sclerotiorum. Again, all treatments significantly reduced disease, with over $50 \%$ control achieved by the $C$. minitans plus single Rovral spray treatment and $85 \%$ control obtained by sprays of Rovral every 2 weeks. In the third crop disease increased to $84 \%$ in the control plots. The single Rovral spray no longer gave control, but both $C$. minitans treatments and the Rovral spray every 2 weeks significantly controlled disease. C. minitans provided nearly $50 \%$ control, but a significantly greater reduction in disease was obtained when $C$. minitans was combined with a single Rovral spray, and this combined treatment was not significantly different to the level of control achieved by Rovral spray every 2 weeks.

In all crops, the number of sclerotia on the soil surface was significantly reduced by all treatments except the single Rovral spray, in comparison to the control (Table 3). In addition, the Rovral spray every 2 weeks reduced sclerotial numbers more than the $C$. minitans only treatment in all three crops, but similar levels of sclerotial reduction were also achieved by $C$. minitans plus single Rovral spray in the first and third crops. The viability of recovered sclerotia was significantly reduced by both $C$. minitans treatments in all three crops (Table 3). There was also a general decline in viability of sclerotia retrieved from control and Rovral sprayed plots between the first and third crops. The percentage of recovered sclerotia that were infected with $C$. minitans was significantly greater in those plots treated with the antagonist. $C$. minitans, however, spread to infect sclerotia in other plots from up to $12 \%$ in the first crop to nearly $74 \%$ by the third crop. There was no difference in the degree that $C$. minitans had spread to infect sclerotia in the control plots or the Rovral treated plots in any crop.

The numbers of CFU of $C$. minitans per $\mathrm{cm}^{3}$ of soil were the same in all $C$. minitans treatments and ranged between 1.6 to $4.2 \times 10^{7}$ at the start of the first crop and between 0.7 to $3.8 \times 10^{7}$ at harvest (data not shown). In the second crop, populations of $C$. minitans ranged from 2.4 to $4.8 \times 10^{7}$ at planting to 0.5 to $2.6 \times$ $10^{7} \mathrm{CFU} / \mathrm{cm}^{3}$ of soil at harvest. In the final crop, CFU ranged between 2.7 to $5.4 \times 10^{7}$ at planting to 0.4 to $3.1 \times 10^{7}$ per $\mathrm{cm}^{3}$ of soil at harvest.

\section{DISCUSSION}

In the in vitro pesticide tests, radial growth and spore germination of all three isolates of $C$. minitans were inhibited similarly by fungicides, with greatest sensitivity toward iprodione and thiram. In soil tray experiments, however, even when the same chemicals were applied at twice the concentration and frequency of application recommended by the manufacturer, no effect on the ability of

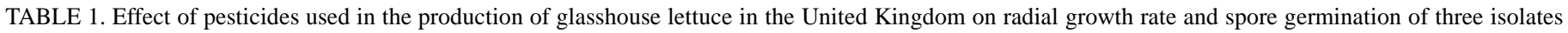
(Conio, IVT-1, and CH1) of Coniothyrium minitans in vitro ${ }^{\mathrm{z}}$

\begin{tabular}{|c|c|c|c|c|c|c|c|}
\hline \multirow[b]{3}{*}{ Pesticide } & \multirow[b]{3}{*}{$\begin{array}{c}\text { Maximum recommended } \\
\text { application rate }\left(\mu \mathrm{g} \text { a.i. } \mathrm{ml}^{-1}\right)\end{array}$} & \multicolumn{6}{|c|}{ Pesticide sensitivity: $\mathrm{EC}_{50}\left(\mu \mathrm{g}\right.$ a.i. $\left.\mathrm{ml}^{-1}\right)$} \\
\hline & & \multicolumn{2}{|c|}{ Conio } & \multicolumn{2}{|c|}{ IVT-1 } & \multicolumn{2}{|c|}{$\mathrm{CH} 1$} \\
\hline & & $\begin{array}{l}\text { Radial } \\
\text { growth }\end{array}$ & $\begin{array}{c}\text { Spore } \\
\text { germination }\end{array}$ & $\begin{array}{l}\text { Radial } \\
\text { growth }\end{array}$ & $\begin{array}{c}\text { Spore } \\
\text { germination }\end{array}$ & $\begin{array}{l}\text { Radial } \\
\text { growth }\end{array}$ & $\begin{array}{c}\text { Spore } \\
\text { germination }\end{array}$ \\
\hline \multicolumn{8}{|l|}{ Fungicides } \\
\hline Iprodione & 500 & 11 & 9 & 14 & 18 & 7 & 10 \\
\hline Mancozeb & 450 & 320 & 300 & 340 & 350 & 290 & 300 \\
\hline Metalaxyl + thiram & $400+2,000$ & 240 & 320 & 190 & 230 & 220 & 280 \\
\hline Thiram & 3,200 & 84 & 68 & 106 & 87 & 92 & 52 \\
\hline Tolclofos-methyl & 700 & 290 & 310 & 330 & 280 & 300 & 280 \\
\hline Zineb & 1,400 & 420 & 360 & 390 & 370 & 340 & 350 \\
\hline \multicolumn{8}{|l|}{ Insecticides } \\
\hline Cypermethrin & 70 & - & - & - & - & - & - \\
\hline Dimethoate & 300 & - & - & - & - & - & - \\
\hline Malathion & 1,920 & 3,200 & 2,600 & 3,000 & 3,200 & 3,700 & - \\
\hline Pirimicarb & 250 & 400 & - & 300 & 3,60 & 280 & - \\
\hline \multicolumn{8}{|l|}{ Herbicide } \\
\hline Chlorpropham + cetrimide & $260+260$ & - & - & - & - & - & - \\
\hline
\end{tabular}

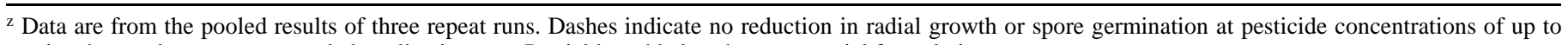
twice the maximum recommended application rate. Pesticides added as the commercial formulation. 
C. minitans to infect and destroy sclerotia was observed. In vitro agar plate or nutrient-broth based experiments are often used as test systems to determine potential tolerance of fungi to pesticides $(2,14,20,38,43)$, but as the results of this study show such systems may not reflect tests conducted in natural environments. A similar difference between pesticide tests carried out in vitro and in soil was found for infection of $S$. minor sclerotia by the mycoparasite Sporidesmium sclerotivorum (1), but these authors did not extend their work to plant- or crop-based experiments.

In vitro agar plate tests may be relevant to application of biocontrol agents to the phylloplane, but additional factors come into play when using inocula applied to soil. For example, there is the dilution factor when pesticides are applied to a volume of soil, particularly if low-volume sprays are involved when most active ingredient will remain near the soil surface. Furthermore, most pesticides in use today are quickly broken down in soil and thus their potential effects on the ability of a biocontrol agent to infect sclerotia may only be short lived. In addition, any biocontrol agent such as $C$. minitans applied as solid substrate inoculum may be less susceptible to the effects of pesticides due to physical protection afforded by the inoculum matrix itself. Thus, the soil tray experiments used in this work appear to provide a more realistic test of pesticide compatibility than agar-incorporation tests for a biocontrol agent aimed for use against the sclerotial stage of $S$. sclerotiorum in soil. In general, assessing compatibility between a biocontrol agent and pesticides in an environment that reflects the planned formulation and application of the biocontrol agent in the field should provide a more reliable measure of compatibility.

The lack of effect of iprodione on $C$. minitans in the tray experiments was reflected in the first glasshouse trial. When combined with a single Rovral spray, there was no difference in efficacy between iprodione-tolerant and standard $C$. minitans isolates in controlling Sclerotinia disease or in decreasing sclerotial numbers and viability, or in infecting sclerotia. Exposure of $C$. minitans to this fungicide application would have been relatively minimal, as at the time of application lettuce plants completely covered the soil surface, and only the recommended concentration was used. Far smaller amounts of fungicide would consequently have reached the soil than those used in the soil-tray experiments.

The design of the glasshouse trials means that in untreated plots, greater numbers of sclerotia are returned to the soil than in those with fungicide or $C$. minitans treatments, potentially magnifying the efficacy of these control treatments. However, this reflects the natural situation in glasshouse lettuce cropping in the United Kingdom if no control measures are applied. The rapid spread of $C$. minitans to untreated control and fungicide treated plots, which has been reported before $(54,55)$, further compounds data interpretation. Thus, $C$. minitans may have suppressed the level of disease developing in these plots, potentially lessening the magnitude of the impact of $C$. minitans observed. Nevertheless, despite these potential problems, reproducible disease control was found using $C$. minitans in both glasshouse trials, demonstrating the robustness of this experimental system, which has been demonstrated previously $(5,6,32,34,50)$.

In both glasshouse trials, significant disease control was achieved using $C$. minitans alone when disease levels built up to over $50 \%$ in control plots. This improved control over previous experiments $(32,33)$ is probably due to the repeated application of C. minitans before each crop rather than a single application to the first crop only. The repeated application of $C$. minitans allows the mycoparasite to come into contact with new sclerotia on the surface of the soil at the start of each crop as well as enabling previously applied inocula to continue to attack sclerotia buried in the soil. Thus the whole sclerotial population is being subjected to a high level of the antagonist. Nevertheless, potentially, with additional introduction of $C$. minitans during sclerotia formation on the crop, perhaps as a foliar spray, the disease could be controlled further. This type of repeated exposure of sclerotial populations of $S$. sclerotiorum to $C$. minitans by foliar sprays has provided longterm field control of Sclerotinia disease in a 5-year trial (16).

The level of control achieved by $C$. minitans was enhanced further in both series of lettuce crops by the single application of a Rovral spray. The level of control achieved with this integrated treatment was statistically as good as that obtained by the use of

TABLE 2. First glasshouse trial: effect of standard and iprodione-tolerant isolates of Coniothyrium minitans applied alone and in combination with single Rovral sprays on the percentage of Sclerotinia sclerotiorum-diseased plants, and the number, viability, and infection of sclerotia of $S$. sclerotiorum by $C$. minitans after harvest of sequential lettuce crops ${ }^{\mathrm{z}}$

\begin{tabular}{|c|c|c|c|c|c|c|c|c|c|c|c|c|}
\hline Treatment & \multicolumn{3}{|c|}{$\%$ Diseased plants } & \multicolumn{3}{|c|}{$\begin{array}{l}\text { Mean number of sclerotia per } \\
500 \mathrm{~cm}^{2} \text { of soil }\end{array}$} & \multicolumn{3}{|c|}{$\%$ Viability of sclerotia } & \multicolumn{3}{|c|}{$\begin{array}{l}\% \text { Sclerotia infected } \\
\text { by } C . \text { minitans }\end{array}$} \\
\hline Control (nil) & $3 \mathrm{a}$ & $63 \mathrm{a}$ & $55 \mathrm{a}$ & $3.0 \mathrm{a}$ & $33.0 \mathrm{a}$ & $47.2 \mathrm{a}$ & n.d. & $81.3 \mathrm{a}$ & $68.2 \mathrm{a}$ & n.d. & $57.5 \mathrm{a}$ & $72.8 \mathrm{a}$ \\
\hline Iprodione-tolerant $C$. minitans & $0 \mathrm{a}$ & $30 \mathrm{~b}$ & $37 \mathrm{a}, \mathrm{b}$ & $0.0 \mathrm{a}$ & $17.6 \mathrm{~b}$ & $29.1 \mathrm{~b}$ & n.d. & $55.8 \mathrm{~b}$ & $59.3 \mathrm{a}, \mathrm{b}$ & n.d & $94.2 \mathrm{~b}$ & $97.1 \mathrm{~b}$ \\
\hline $\begin{array}{l}\text { Standard C. minitans + Rovral } \\
\text { Iprodione-tolerant } C \text { minitans }\end{array}$ & $1 \mathrm{a}$ & $17 \mathrm{~b}$ & $22 \mathrm{c}$ & $1.5 \mathrm{a}$ & $9.8 \mathrm{~b}$ & $18.8 \mathrm{~b}$ & n.d. & $35.0 \mathrm{~b}$ & $44.9 \mathrm{c}$ & n.d & $95.4 \mathrm{~b}$ & $89.6 \mathrm{~b}$ \\
\hline $\begin{array}{l}\text { Iprodione-tolerant C. minitans }+ \\
\text { Rovral }\end{array}$ & $2 \mathrm{a}$ & $19 \mathrm{~b}$ & $24 \mathrm{c}$ & $1.3 \mathrm{a}$ & $14.4 \mathrm{~b}$ & $24.7 \mathrm{~b}$ & n.d. & $47.9 \mathrm{~b}$ & $56.2 \mathrm{~b}$ & n.d & $92.5 \mathrm{~b}$ & $94.5 \mathrm{~b}$ \\
\hline
\end{tabular}

${ }^{\mathrm{z}}$ C. minitans applied as maizemeal-perlite solid substrate inoculum $\left(0.6\right.$ liters $\left.\mathrm{m}^{-2}\right)$. Single Rovral spray applied at onset of disease $\left(0.5 \mathrm{~kg} \mathrm{a}^{-1}\right)$. Numbers in the same columns followed by the same letters are not significantly different according to least significant difference $(P<0.05)$ based on the $F$ test in analysis of variance. Not determined due to lack of sclerotia.

TABLE 3. Second glasshouse trial: effect of Coniothyrium minitans alone and in combination with a single Rovral spray in comparison with single and Rovral sprays every 2 weeks on the percentage of Sclerotinia sclerotiorum-diseased plants, and the number, viability and infection of sclerotia of $S$. sclerotiorum by $C$. minitans after harvest of sequential lettuce crops $^{\mathrm{z}}$

\begin{tabular}{|c|c|c|c|c|c|c|c|c|c|c|c|c|}
\hline Treatment & \multicolumn{3}{|c|}{$\%$ Diseased plants } & \multicolumn{3}{|c|}{$\begin{array}{l}\text { Mean number of sclerotia } \\
\text { per } 500 \mathrm{~cm}^{2} \text { of soil }\end{array}$} & \multicolumn{3}{|c|}{$\%$ Viability of sclerotia } & \multicolumn{3}{|c|}{$\begin{array}{l}\% \text { Sclerotia infected } \\
\text { by } C . \text { minitans }\end{array}$} \\
\hline Con & $12 \mathrm{a}$ & 32 & $84 \mathrm{a}$ & $19.6 \mathrm{a}$ & 34. & 71. & 060 & 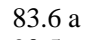 & 79. & $12.7 \mathrm{a}$ & $\mathrm{a}$ & 63.3 \\
\hline Rovral spray every 2 weeks & $5 \mathrm{~b}$ & $5 \mathrm{~b}$ & $21 \mathrm{c}$ & $5.8 \mathrm{c}$ & $6.2 \mathrm{c}$ & $23.2 \mathrm{c}$ & $95.8 \mathrm{a}$ & 88.9 a & $80.5 \mathrm{a}$ & $9.5 \mathrm{a}$ & $27.8 \mathrm{a}$ & $68.7 \mathrm{a}$ \\
\hline C. minitans & $7 \mathrm{~b}$ & $19 \mathrm{~b}$ & $44 \mathrm{~b}$ & $11.1 \mathrm{~b}$ & $19.7 \mathrm{~b}$ & $39.3 \mathrm{~b}$ & $59.3 \mathrm{~b}$ & $60.7 \mathrm{~b}$ & $62.6 \mathrm{~b}$ & $90.2 \mathrm{~b}$ & $98.2 \mathrm{~b}$ & $91.5 \mathrm{~b}$ \\
\hline C. minitans + single Rovral spray & $1 \mathrm{~b}$ & $15 \mathrm{~b}$ & $29 \mathrm{c}$ & $3.4 \mathrm{c}$ & $15.9 \mathrm{~b}$ & $28.4 \mathrm{~b}, \mathrm{c}$ & $62.7 \mathrm{~b}$ & $63.1 \mathrm{~b}$ & $58.9 \mathrm{~b}$ & $97.6 \mathrm{~b}$ & $89.1 \mathrm{~b}$ & $95.9 \mathrm{~b}$ \\
\hline
\end{tabular}

${ }^{z}$ C. minitans applied as maizemeal-perlite solid substrate inoculum $\left(0.6\right.$ liters $\left.\mathrm{m}^{-2}\right)$. Single Rovral spray applied at onset of disease $\left(0.5 \mathrm{~kg}^{-1}\right)$. Numbers in the same columns followed by the same letters are not significantly different according to least significant difference $(P<0.05)$ based on the $F$ test in analysis of variance. 
prophylactic spraying of Rovral. The ability of $C$. minitans to infect sclerotia found on the diseased lettuce was not inhibited by the single Rovral spray, nor by the standard Rovral spray regime. C. minitans spread into the plots treated with Rovral every 2 weeks just as efficiently as in the control plots. Therefore, Rovral sprays appear to have no adverse influence on the capacity of $C$. minitans to spread to nontreated plots, infect sclerotia, or reduce disease and the subsequent number of new sclerotia formed. As $C$. minitans cannot grow through soil $(54,55)$, spread of $C$. minitans by water splash or mesofauna $(54,55)$ may be important in developing field-scale suppression of Sclerotinia disease, which has been associated with $C$. minitans previously $(23,30)$.

These trials show the potential for the use of $C$. minitans in an integrated program to control Sclerotinia disease in glasshouse lettuce. The timing of application of fungicide is, however, very important. Through the experience of running many trials involving S. sclerotiorum on lettuce we were able to apply Rovral at the optimum time that a single application would have the most effect, just as the disease was beginning to proliferate (26). There is no reason, however, why the onset of disease could not be predicted more accurately in glasshouse-grown lettuce, if more research was carried out on environmental effects on sclerotial germination and lettuce infection in this cropping system. Such studies have proven successful recently for Sclerotinia stem rot in spring-sown oilseed rape (46). With targeted application of fungicides to lettuce or other crops at the most susceptible stages of the pathogen life cycle, fewer fungicide applications might be required, and they might be more effective. Evidence from a 4-year series of field trials comparing routine benomyl sprays with foliar applications of microbial antagonists, including $C$. minitans, for control of $S$. sclerotiorum on bean, indicated that benomyl provided consistent, reproducible control but the microbial antagonists gave reproducible control in certain years only (3). This may be due to environmental factors influencing the ability of microbial antagonists to control ascospore infection of petals by S. sclerotiorum (19). Thus, fungicide sprays may provide a more stable control of $S$. sclerotiorum than microbial antagonists at this stage of the life cycle of the pathogen (3). Mycoparasitic biocontrol agents such as $C$. minitans, however, may be more valuable to decrease production of sclerotia on the plant or to attack sclerotia formed on plant tissue later in the life cycle $(18,44)$ particularly if the strains are tolerant of the pesticides in use. In addition, $C$. minitans may be valuable in attacking sclerotia already in the soil that are not so susceptible to attack by chemicals $(6,22,30,31)$ and to clean-up $S$. sclerotiorum-infested seed lots by eliminating sclerotia that fungicide treatments alone cannot eliminate (33).

\section{ACKNOWLEDGMENTS}

This work was funded by the Ministry of Agriculture, Fisheries, and Food (MAFF) for England and Wales. We thank A. Jackson for help with the statistical design and analysis, J. Fenlon for further biometrics advice, and the nursery staff for their assistance with glasshouse experiments at Horticulture Research International, Littlehampton, where all work was carried out.

\section{LITERATURE CITED}

1. Adams, P. B., and Wong, J. A.-L. 1991. The effect of chemical pesticides on the infection of sclerotia of Sclerotinia minor by the biocontrol agent Sporidesmium sclerotivorum. Phytopathology 81:1340-1343.

2. Benyagoub, M., and Bélanger, R. R. 1995. Development of a mutant strain of Sporothrix flocculosa with resistance to dodemorph-acetate. Phytopathology 85:766-770.

3. Boland, G. J. 1997. Stability analysis for evaluating the influence of environment on chemical and biological control of white mold (Sclerotinia sclerotiorum) of bean. Biol. Control 9:7-14.

4. Brannen, P. M., and Backman, P. A. 1994. Suppression of Fusarium wilt of cotton with Bacillus subtilis hopper box formulations. Pages 83-85 in: Improving Plant Productivity with Rhizosphere Bacteria. M. H. Ryder, P.
M. Stephens, and G. D. Bowen, eds. CSIRO Division of Soils, Adelaide, Australia.

5. Budge, S. P., McQuilken, M. P., Fenlon, J. S., and Whipps, J. M. 1995. Use of Coniothyrium minitans and Gliocladium virens for biological control of Sclerotinia sclerotiorum in glasshouse lettuce. Biol. Control 5:513-522.

6. Budge, S. P., and Whipps, J. M. 1991. Glasshouse trials of Coniothyrium minitans and Trichoderma species for the biological control of Sclerotinia sclerotiorum in celery and lettuce. Plant Pathol. 40:59-66.

7. Chand-Goyal, T., and Spotts, R. A. 1996. Postharvest biological control of blue mold of apple and brown rot of sweet cherry by natural saprophytic yeasts alone or in combination with low doses of fungicides. Biol. Control 6:253-259.

8. Conway, K. E., Maness, N. E., and Motes, J. E. 1997. Integration of biological and chemical controls for Rhizoctonia aerial blight and root rot of rosemary. Plant Dis. 81:795-798.

9. Cubeta, M. A., and Echandi, E. 1991. Biological control of Rhizoctonia and Pythium damping-off of cucumber: An integrated approach. Biol. Control 1:227-236.

10. Droby, S., Cohen, L., Daus, A., Weiss, B., Horev, B., Chalutz, E., Katz, H., Keren-Tzur, M., and Shachnai, A. 1998. Commercial testing of Aspire: A yeast preparation for the biological control of postharvest decay of citrus. Biol. Control 12:97-101.

11. El-Shanshoury, A. R., Abu El-Sououd, S. M., Awadalla, O. A., and El-Bandy, N. B. 1995. Effects of Streptomyces corchorusii, Streptomyces mutabilis, pendimethalin, and metribuzin on the control of bacterial and Fusarium wilt of tomato. Can. J. Bot. 74:1016-1022.

12. Elad, Y. 1994. Biological control of grape grey mould by Trichoderma harzianum. Crop Prot. 13:35-38.

13. Elad, Y., Zimand, G., Zaqs, Y., Zuriel, S., and Chet, I. 1993. Use of Trichoderma harzianum in combination or alternation with fungicides to control cucumber grey mould (Botrytis cinerea) under commercial greenhouse conditions. Plant Pathol. 42:324-332.

14. Fernando, W. G. D., and Linderman, R. G. 1994. Chemical control of stem and root rot of cowpea caused by Phytophthora vignae. Plant Dis. 78:967-971.

15. Fravel, D. R., Connick, W. J., Jr., and Lewis, J. A. 1998. Formulation of microorganisms to control plant diseases. Pages 187-202 in: Formulation of Microbial Biopesticides: Beneficial Microorganisms, Nematodes, and Seed Treatments. H. D. Burges, ed. Kluwer Academic Publishers, Dordrecht, Netherlands.

16. Gerlagh, M., Goosen-van de Geijn, H. M., Fokkema, N. J., and Vereijken, P. F. G. 1999. Long-term biosanitation by application of Coniothyrium minitans on Sclerotinia sclerotiorum-infected crops. Phytopathology 89:141-147.

17. Gerlagh, M., and Vos, I. 1991. Enrichment of soil with sclerotia to isolate antagonists of Sclerotinia sclerotiorum. Pages 165-171 in: Biotic Interactions and Soil-borne Diseases. A. B. R. Beemster, G. J. Bollen, M. Gerlagh, M. A. Ruissen, B. Schippers, and A. Tempel, eds. Elsevier Scientific Publishing, Amsterdam, Netherlands.

18. Gerlagh, M., Whipps, J. M., Budge, S. P., and Goossen-van de Geijn, H. M. 1996. Efficiency of isolates of Coniothyrium minitans as mycoparasites of Sclerotinia sclerotiorum, Sclerotium cepivorum, and Botrytis cinerea on tomato stem pieces. Eur. J. Plant Pathol. 102:787-793.

19. Hannusch, D. J., and Boland, G. J. 1996. Influence of air temperature and relative humidity on biological control of white mold of bean (Sclerotinia sclerotiorum). Phytopathology 86:156-162.

20. Harman, G. E., Latorre, B., Agosin, E., San Martin, R., Riegel, D. G., Nielsen, P. A., Tronsmo, A., and Pearson, R. C. 1996. Biological and integrated control of Botrytis bunch rot of grape using Trichoderma spp. Biol. Control 7:259-266.

21. Heydari, A., and Misaghi, I. J. 1998. Biocontrol activity of Burkholderia cepacia against Rhizoctonia solani in herbicide-treated soils. Plant Soil 202:109-116.

22. Huang, H. C. 1980. Control of Sclerotinia wilt of sunflower by hyperparasites. Can. J. Plant Pathol. 2:26-32.

23. Huang, H. C., and Kozub, G. C. 1991. Monocropping to sunflower and decline of Sclerotinia wilt. Bot. Bull. Acad. Sin. 32:163-170.

24. Korsten, L., De Villiers, E. E., Wehner, F. C., and Kotzé, J. M. 1997. Field sprays of Bacillus subtilis and fungicides for control of preharvest fruit diseases of avocado in South Africa. Plant Dis. 81:455-459.

25. Lindow, S. E., McGourty, G., and Elkins, R. 1996. Interactions of antibiotics with Pseudomonas fluorescens strain A506 in the control of fire blight and frost injury to pear. Phytopathology 86:841-848.

26. Lynch, L. M., and Ebben, M. H. 1986. The use of microorganisms to control plant disease. J. Appl. Bacteriol. Symp. Supp. 1986:S115-126.

27. Mahaffee, W. F., and Backman, P. A. 1993. Effects of seed factors on spermosphere and rhizosphere colonization of cotton by Bacillus subtilis GB03. Phytopathology 83:1120-1125.

28. Marois, J. J., Johnston, S. A., Dunn, M. T., and Papavizas, G. C. 1982. 
Biological control of Verticillium wilt of eggplant in the field. Plant Dis. 66:1166-1168.

29. Mathre, D. E., Johnston, R. H., Callan, N. W., Mohan, S. K., Martin, J. M., and Miller, J. B. 1995. Combined biological and chemical seed treatments for control of two seedling diseases of Sh2 sweet corn. Plant Dis. 79:1145-1148.

30. McLaren, D. L., Huang, H. C., Kozub, G. C., and Rimmer, S. R. 1994. Biological control of Sclerotinia wilt of sunflower with Talaromyces flavus and Coniothyrium minitans. Plant Dis. 78:231-235.

31. McLaren, D. L., Huang, H. C., and Rimmer, S. R. 1996. Control of apothecial production of Sclerotinia sclerotiorum by Coniothyrium minitans and Talaromyces flavus. Plant Dis. 80:1373-1378.

32. McQuilken, M. P., Budge, S. P., and Whipps, J. M. 1997. Production, survival and evaluation of liquid culture-produced inocula of Coniothyrium minitans against Sclerotinia sclerotiorum. Biocontrol Sci. Technol. 7:23-36.

33. McQuilken, M. P., Budge, S. P., and Whipps, J. M. 1997. Biological control of Sclerotinia sclerotiorum by film-coating Coniothyrium minitans on to sunflower seed and sclerotia. Plant Pathol. 46:919-929.

34. McQuilken, M. P., and Whipps, J. M. 1995. Production, survival, and evaluation of solid-substrate inocula of Coniothyrium minitans against Sclerotinia sclerotiorum. Eur. J. Plant Pathol. 101:101-110.

35. Minuto, A., Migheli, Q., and Garibaldi, A. 1995. Evaluation of strains of Fusarium spp. in the biological and integrated control of Fusarium wilt of cyclamen. Crop Prot. 14:221-226.

36. Papavizas, G. C., and Lewis, J. A. 1983. Physiological and biocontrol characteristics of stable mutants of Trichoderma viride resistant to MBC fungicides. Phytopathology 73:407-411.

37. Papavizas, G. C., and Lewis, J. A. 1988. The use of fungi in integrated control of plant diseases. Pages 235-253 in: Fungi in Biological Control Systems. M. N. Burge, ed. Manchester University Press, Manchester, U.K.

38. Papavizas, G. C., Roberts, D. P., and Kim, K. K. 1990. Developments of mutants of Gliocladium virens tolerant to benomyl. Can. J. Microbiol. 36:484-489.

39. Sugar, D., and Spotts, R. A. 1999. Control of postharvest decay in pear by four laboratory-grown yeasts and two registered biocontrol products. Plant Dis. 83:155-158.

40. Sundheim, L., and Amundsen, T. 1982. Fungicide tolerance in the hyperparasite Ampelomyces quisqualis and integrated control of cucumber powdery mildew. Acta Agric. Scand. 32:349-355.

41. Sztejnberg, A., Galper, S., Mazar, S., and Lisker, N. 1989. Ampelomyces quisqualis for biological and integrated control of powdery mildew in Isr. J. Phytopathol. 124:285-295.

42. Tirilly, Y. 1991. The role of fosetyl-Al in the potential integrated control of Fulvia fulva. Can. J. Bot. 69:306-310.

43. Tronsmo, A. 1991. Biological and integrated controls of Botrytis cinerea on apple with Trichoderma harzianum. Biol. Control 1:59-62.

44. Trutmann, P., Keane, P. J., and Merriman, P. R. 1982. Biological control of Sclerotinia sclerotiorum on aerial parts of plants by the hyperparasite Coniothyrium minitans. Trans. Brit. Mycol. Soc. 78:521-529.

45. Turner, G. J., and Tribe, H. T. 1976. On Coniothyrium minitans and its parasitism of Sclerotinia species. Trans. Brit. Mycol. Soc. 66:97-104.

46. Twengström, E. 1998. Forecasting Sclerotinia stem rot in spring sown oilseed rape. Crop. Prot. 17:405-411.

47. Utkhede, R. S., and Smith, E. M. 1993. Long-term effects of chemical and biological treatments on crown and root rot of apple trees caused by Phytophthora cactorum. Soil Biol. Biochem. 25:383-386.

48. Whipps, J. M. 1992. Status of biological disease control in horticulture. Biocontrol Sci. Technol. 2:3-24.

49. Whipps, J. M., and Budge, S. P. 1990. Screening for sclerotial mycoparasites of Sclerotinia sclerotiorum. Mycol. Res. 94:607-612.

50. Whipps, J. M., Budge, S. P., and Ebben, M. H. 1989. Effect of Coniothyrium minitans and Trichoderma harzianum on Sclerotinia disease of celery and lettuce in the glasshouse at a range of humidities. Pages 233-243 in: Integrated Pest Management in Protected Crops. R. Cavalloro and C. Pelerents, eds. Balkema, Rotterdam, Netherlands.

51. Whipps, J. M., Budge, S. P., and Mitchell, S. J. 1993. Observations on sclerotial mycoparasites of Sclerotinia sclerotiorum. Mycol. Res. 97:697-700

52. Whipps, J. M., and Gerlagh, M. 1992. Biology of Coniothyrium minitans and its potential for use in disease biocontrol. Mycol. Res.11:897-907.

53. Whitehead, R. (ed.) 1999. The UK Pesticide Guide. CABI Publishing, Wallingford, U.K.

54. Williams, R. H., Whipps, J. M., and Cooke, R. C. 1998. The role of mesofauna in dispersal of Coniothyrium minitans: Transmission to sclerotia of Sclerotinia sclerotiorum. Soil Biol. Biochem. 30:1929-1935.

55. Williams, R. H., Whipps, J. M., and Cooke, R. C. 1998. Splash dispersal of Coniothyrium minitans in the glasshouse. Ann. Appl. Biol. 132:77-90.

56. Woodgate-Jones, P., and Hunter, T. 1983. Integrated control of Chondrostereum purpureum in plum by treatment of pruning wounds. J. Hort. Sci. 58:491-495.

57. Zablotowcz, R. M., Press, C. M., Lyng, N., Brown, G. L., and Kloepper, J. W. 1992. Compatibility of plant growth promoting rhizobacterial strains with agrichemicals applied to seed. Can. J. Microbiol. 38:45-50.

58. Zaki, K., Misaghi, I. J., Heydari, A., and Shatla, M. N. 1998. Control of cotton seedling damping-off in the field by Burkholderia (Pseudomonas) cepacia. Plant Dis. 82:291-293.

59. Zhou, T., and Reeleder, R. D. 1989. Application of Epicoccum purpurascens spores to control white mold of snap bean. Plant Dis. 73:639-642.

60. Zhou, T., and Reeleder, R. D. 1990. Selection of strains of Epicoccum purpurascens for tolerance to fungicides and improved biocontrol of Sclerotinia sclerotiorum. Can. J. Microbiol. 36:754-759. 